\title{
Touch DNA; A Quantitative Study in the Perspective of Forensic Science
}

\section{Avinash Kumar* \\ State Forensic Science Laboratory, J harkhand, India \\ *Corresponding author: Avinash Kumar, State Forensic Science Laboratory, J harkhand, India}

Received: January 25, 2021; Accepted: February 15, 2021; Published: February 22, 2021

\begin{abstract}
"Touch DNA" is a DNA obtained from biological material transferred from a source to an object or a person during physical contact. Touch DNA came into notice after the research work of Ronald van oorschot, he focused on DNA from fingerprint. We usually use the "Swabbing" and "cutting out" Technique for collection of Touch DNA. Organic method of extraction is most favoured, followed by RT-PCR for quantitation of DNA. Belonging's used in day-to-day life holds an ample amount of DNA like Brush, Smart phone, Mask, Toothpicks etc, which is quite sufficient to generate a DNA profile of any individual. It can be a very valuable source to establish the identity and individuality of any person in the field of forensic science.
\end{abstract}

Keywords: Biological; Fingerprint; Swabbing; RT PCR; Quantitation; Extraction; Forensic science

\section{Introduction}

"Touch DNA" is a DNA obtained from biological material transferred from a donor to an object or person during a physical contact [1]. It is a minute sample which can not be found easily at the crime scene, ittotally depends upon the efficiency of the investigating officer. Touch DNA plays an important role in capturing any suspects and bring justice to any victim because "according to the forensic's principle of exchange (locard's principle), every contact leaves a trace" [1].

Ronald van oorschot et al., in 1997 it revealed that DNA could be detected not just from bodily fluid but from the traces left by a touch [2]. It is indirect evidence where biological fluid is not found. In India this type of evidence are ignored by the investigator officer due to lack of knowledge. In criminal cases, sampling technique is very important to collect the valuable evidence. The most common technique is collection of "cellular material" and "swab technique". In this technique, we use sterile cotton for swabbing on the surface of the object. To improve the quality of the resulting DNA profile, the double swab technique is usually applied (Wet and Dry). Another sampling technique frequently used in large number of forensic science laboratories is, "cutting out the area of interest", this method is especially applied to soft items [3].

\section{Material and Methods}

\section{Sample preparation}

The sample taken for DNA extraction from these sources are listed in the (Table 1).

The swabbing was taken with the help NS water. Put it in the room temperature to dry and then pack it in the paper envelop. The sample were cut in small pieces with the help of clean scissors and allowed to soak in lysis buffer.

\section{DNA isolation or extraction}

Sample was subjected to organic extraction method for DNA isolation. Sample submerged in $400 \mu \mathrm{l}$ of extraction buffer $(1.21 \mathrm{~g}$ TRIS, $5.84 \mathrm{gNacl}$, Adjust $\mathrm{pH}$ to 8.0 with HCL, Add $100 \mathrm{ml} 20 \%$ SDS, Add $20 \mathrm{ml} 0.5 \mathrm{M} \mathrm{Na}$ EDTA-2 $\mathrm{H}_{2} \mathrm{O}$ Add $6.02 \mathrm{mg} \mathrm{DTT} / \mathrm{ml}$ ) in $1.5 \mathrm{ml}$ of microcentrifuge tube $(1.5 \mathrm{ml})$ then $10 \mu$ l Proteinase $\mathrm{K}$ was added and incubated for 2 hours at $56^{\circ} \mathrm{C}$ on water bath. After incubation an equal volume of Phenol: Chloroform: Isoamyl alcohol (25:24:1) was added to each tube then mixed by inverting the tube up and down for 2 minutes. The tubes were then centrifuged at $10000 \mathrm{rpm}$ for 5-6 min. The upper aqueous layer was then transferred in separate microcentrifuge tube $(1.5 \mathrm{ml})$. Then purification of DNA was done by precipitation with absolute ethanol (2X) and kept at $-20^{\circ} \mathrm{C}$ for $30 \mathrm{~min}$ to settle down. After incubation, tubes were then centrifuged at 14000 $\mathrm{rpm}$ for $15 \mathrm{~min}$. The pellet of DNA was washed with $70 \%$ ethanol to remove remnant salts and dried at room temperature. Add 20-30 $\mu \mathrm{lTE}$ buffer must place in water bath (15-30 minute).Place it in $-20^{\circ} \mathrm{C}$ for store purpose.

\section{DNA quantification}

The Real-Time Polymerase Chain Reaction (RT-PCR) was performed for the DNA quantification of the samples (Table 1) by using the Quantifiler Human DNA Quantification kit (Life Technologies Inc). This kit provides the PCR reaction mix (Human Quantifier), primer sets (Human Quantifier) and standard DNA. RT-PCR reaction setup of $25 \mu \mathrm{l}$ includes $10.5 \mu \mathrm{l}$ of primer sets, $12.5 \mu \mathrm{l}$ of reaction mix and $2 \mu \mathrm{l}$ of DNA templates to each well and run the PCR using Real-Time PCR machine (Applied Biosystems) and model

Table 1: Sample.
\begin{tabular}{|c|c|c|}
\hline S. No & Source & Sample for DNA Extraction \\
\hline 1 & Mobile phone & Swabbing \\
\hline 2 & Mask & Cutting \\
\hline 3 & Tooth pick & Cutting \\
\hline 4 & Comb & Swabbing \\
\hline 5 & Brush & Cutting \\
\hline 6 & Inner sole of the shoe & Swabbing \\
\hline
\end{tabular}




\begin{tabular}{|c|c|c|c|c|c|}
\hline S. No & Source & Target & Task & Quantity & CT \\
\hline 1 & Inner-shoe & $\begin{array}{l}\text { Duo Human } \\
\text { Duo IPC } \\
\text { Duo Male }\end{array}$ & $\begin{array}{l}\text { Unknown } \\
\text { Unknown } \\
\text { unknown }\end{array}$ & $\begin{array}{c}0.0043 \\
- \\
0.0174\end{array}$ & $\begin{array}{l}37.3053 \\
29.6094 \\
37.0468\end{array}$ \\
\hline 2 & Comb & $\begin{array}{l}\text { Duo Human } \\
\text { Duo IPC } \\
\text { Duo Male }\end{array}$ & $\begin{array}{l}\text { Unknown } \\
\text { Unknown } \\
\text { Unknown }\end{array}$ & $\begin{array}{l}- \\
- \\
-\end{array}$ & $\begin{array}{c}\text { Undetermined } \\
29.4941 \\
\text { Undetermined }\end{array}$ \\
\hline 3 & Tooth-pick & $\begin{array}{l}\text { Duo Human } \\
\text { Duo IPC } \\
\text { Duo Male }\end{array}$ & $\begin{array}{l}\text { Unknown } \\
\text { Unknown } \\
\text { Unknown }\end{array}$ & $\begin{array}{c}8.5628 \\
- \\
7.8999\end{array}$ & $\begin{array}{c}26.3779 \\
26.6673 \\
27.254\end{array}$ \\
\hline 4 & Brush & $\begin{array}{l}\text { Duo Human } \\
\text { Duo IPC } \\
\text { Duo Male }\end{array}$ & $\begin{array}{l}\text { Unknown } \\
\text { Unknown } \\
\text { Unknown }\end{array}$ & $\begin{array}{c}0.028 \\
- \\
0.0376\end{array}$ & $\begin{array}{c}34.6078 \\
29.8518 \\
35.183\end{array}$ \\
\hline 5 & Mobile swabbing & $\begin{array}{l}\text { Duo Human } \\
\text { Duo IPC } \\
\text { Duo Male }\end{array}$ & $\begin{array}{l}\text { Unknown } \\
\text { Unknown } \\
\text { Unknown }\end{array}$ & $\begin{array}{c}0.0478 \\
- \\
0.0783\end{array}$ & $\begin{array}{c}33.838 \\
29.7546 \\
34.6403\end{array}$ \\
\hline 6 & Mask & $\begin{array}{l}\text { Duo Human } \\
\text { Duo IPC } \\
\text { Duo Male }\end{array}$ & $\begin{array}{l}\text { Unknown } \\
\text { Unknown } \\
\text { Unknown }\end{array}$ & $\begin{array}{c}0.6372 \\
- \\
0.9187\end{array}$ & $\begin{array}{l}30.1145 \\
29.6081 \\
30.6981\end{array}$ \\
\hline
\end{tabular}

number variti.

\section{Result and Discussion}

The samples taken, were daily purpose material like, shoes, toothpicks, brush, mobile and masks, it was dissolved in $10 \mu \mathrm{l}$ of TE Buffer, and the following findings were observed (Table 2) a little amount of human male DNA was found, on the contrary the comb gave a negative result, which may be due to the presence of inhibitor, Touch DNA can be used as a source of evidence when the bodily fluids are not present in the scene of crime. The observed data indicates that the amount of DNA extracted from the touch DNA source can be sufficient to generate a DNA profile of an individual, if advanced amplification unit is available.

\section{Conclusion}

Due to the sudden pandemic-like condition, the use of mask is a 'must', like any other necessary clothing it has also occupied a place in the life of the primate .It is the most efficient evidence in today's era as it is a the rich source of DNA but on the contrary it is being neglected, Generally nasal fluid saliva and sweat soaked by the mask, so investigating officer should not miss a chance to collect this potential evidence. There are many other belongings, which a human carries in his day to day life, the most common is the smart-phone. Sweat and saliva are the primary source of 'Touch DNA' in the smart phone, which is ignored and jeopardizing this fingerprint are used instead as a source of evidence. DNA is the most precise and accurate form of evidence to carry out investigation.

The other important source of touch DNA could be tooth pick, brush, inner-shoe swabbing etc, which can be found at the scene of occurrence. Thus the investigating officer should be made more familiar about the significance of touch DNA.

\section{Acknowledgement}

I would like to express my sincere gratitude to State Forensic Science Laboratory, Ranchi, Jharkhand for providing me an opportunity, through which I was able to complete this research. I sincerely thank, Dr. A.K. Bapuli (Director, SFSL, Ranchi).

Mr. Mukund Kumar Sinha (Assistant Director, DNA Division, SFSL, Ranchi).

Dr. Amitkumar, ShriBinitBaraik, Shri Ajay Kumar (Scientific Assistant, DNA Division, SFSL, Ranchi).

\section{References}

1. Sessa F, Salerno M, Bertozzi G, Messina G, Ricci P, Ledda C, et al. Touch DNA: impact of handling time on touch deposit and evaluation of different recovery techniques: An experimental study. Sci Rep. 2019; 9: 9542.

2. van Oorschot R, Jones M. DNA fingerprints from fingerprints. Nature. 1997; 387: 767.

3. Sumanta, Yadav VK, Bara N, Sinha HK, Singh RS. DNA Profiling of a Rape Case at the State Forensic Science Laboratory Ranchi Jharkhand India. Austin J Forensic Sci Criminol. 2017; 4: 1068. 